\title{
Three laws of branding: Neuroscientific foundations of effective brand building
}

Received (in revised form): 14 November, 2007

\section{TJACO H.WALVIS}

is a partner at THEY, a brand management consulting firm based in Amsterdam, the Netherlands. Before that, he was with BBDO. MrWalvis advises on (creative) brand and communication strategy issues, including brand positioning, extensions, portfolio management and location branding (eg nations). He has worked with brands in a broad range of industries, including fashion, fast mover consumer goods, financial services, government, insurance, media, pharmaceuticals, private banking, postal services, publishing, retail, telecommunications and world expositions. Clients include Amsterdam Airport Schiphol, DaimlerChrysler, Dorito's, Mars, McKinsey \& Company, Robeco, Sanoma Publishers and many others. MrWalvis holds two Master degrees, in economics (MSc) and philosophy (MA), both from Erasmus University Rotterdam. He is married, with three children, and lives and works in Amsterdam.

\section{Keywords}

branding; memory-based brand choice; branding laws; neuroscience; neuromarketing
Tjaco H.Walvis THEY

Paul van Vlissingenstraat 6C

1096 BK Amsterdam

The Netherlands.

Tel: + 3I(0)20 4953200

Fax: + 31 (0)204953210

E-mail: tjaco@they.nl

\section{Abstract}

Commercial brands strive to be chosen by customers, and branding as an activity is aimed at increasing the likelihood that they are. Almost all customer choices are at least partially memorybased. This paper begins with the assumption that as neuroscience is a 'hard' science studying memory as a highly regular subject matter, it should be possible to deduce several laws from it for the 'soft' field of branding. Based on primary, empirical research in neuroscience, the author synthesises three laws that govern the probability that a brand enters our awareness as a positive candidate for choice. Brands that have been built in accordance with these laws have a higher probability of being chosen than brands in the same category that have not. Journal of Brand Management (2008) 16, 176-194. doi:10.1057/palgrave.bm.2550139; published online 28 December 2007

\section{INTRODUCTION}

Marketers around the world spend billions of dollars a year in the pursuit of building strong brands. Study after study demonstrates that strong brands create higher amounts of shareholder value, by increasing revenue and margin growth and decreasing the riskiness of a company's cash flows, more effectively than weak brands (see Millward Brown, ${ }^{1}$ Interbrand ${ }^{2}$ and Madden et $a .^{3}{ }^{3}$. According to some authors of popular management books, building such brands requires the application of simple 'laws' of branding (see, eg Alsop $^{4}$ and Ries and Ries ${ }^{5}$ ). These books, however, often claim to be based on practical experience instead of on systematic research. Hence, writers of such books seem to use the word 'laws' for rhetorical, and not scientific reasons.

The value of branding laws - if they were available - is quite evident. For example, they would help practitioners make better branding decisions if they could rely on a set of solid principles and these could then provide fruitful hypotheses for academic research. So are there laws in branding? Are there universal, reliable principles marketers can use in their efforts to influence the choice processes of customers and stakeholders in their own favour by building powerful brands? And if so, what do they look like? This is the central issue this paper aims to address.

The obvious first remark is an argument against such a claim. Social science-to 
which the study of branding belongs-is not characterised by the presence of rules and principles with the immutability of the laws we find in the exact sciences. Within the field of economics, the most exact of the social sciences, a number of 'laws' exist, such as the law of diminishing returns, the law of supply and demand and the law of one price. Yet, they are law-like regularities more than laws in the classical scientific sense. As Mark Blaug, ${ }^{6}$ a prominent economic methodologists, states, if by a law we mean well-corroborated, universal relations between events deduced from independently tested initial conditions, few modern economists would claim that economics has so far produced more than one or two laws'.

Nevertheless, based on an extensive study of the neurobiological literature, the author believes that it is possible to describe several robust, general findings from the 'hard' and exact field of neuroscience and deduce implications from them for the 'soft' field of branding. This paper describes this process, and results in the identification of three branding notions. These notions are rooted in highly regular neuroscientific phenomena from which they acquire a law-like regularity, justifying the label 'branding laws'. This paper, then, makes the claim that as these laws are deduced from neuroscience, which is an exact science, they bear a reliability that could not be attained previously by relying on traditional branding research and literature alone.

As such, this study contributes to the integration of neurobiological research within the field of brand management. This development can be seen as a logical next step in the tendency to pay more attention to the role of memory in brand choice. After Lynch and Srull ${ }^{7}$ made the point that consumer choice is seldom purely stimulus-based, memory became a topic in its own right. ${ }^{8}$ With Fazio's 9 model of attitude-behaviour relationships, the accessibility of brand attitudes became an area of interest. Nedungadi and Hutchinson ${ }^{10}$ showed that brand recall is strongly correlated with brand choice and Holden and Lutz ${ }^{11}$ refined such analyses by showing that brand recall is often set in motion by consumption goals and occasions. Later, the importance of implicit and unconscious factors in choice received attention (see, eg Lee ${ }^{12}$ ). This paper extends this literature with neurobiological findings on memory formation and retrieval, based on the literature review, and derives consequences for the practice of branding in the form of three branding laws.

Two limitations of this study must be acknowledged at the outset. The first is that the branding principles referred to are already known and have been separately and adequately documented before. As such, they do not represent radical new discoveries in themselves. The author contends, however, that, first, by uncovering and recognising these principles as laws and, secondly, by combining them, an interesting foundation arises that can benefit both practitioners and academics. Experience suggests that these laws hold a number of consequences that are not being implemented by planners, media strategists, marketers and brand managers with the rigour that they deserve.

The second limitation the author would like to note is the fact that the field of neuroscience is in development and that some deeper aspects of the topics discussed-although they are not wild speculations-have not been finally resolved. The author, therefore, presents a 'branding law theorem' in this paper that he believes is fruitful and that he would like to put forward for further debate and 
research-given the current state of its neurological foundation.

In presenting its thesis, this paper first looks at several current developments at the boundary between marketing and neuroscience to create a context. Next, it clarifies the definitions of brands and branding that it takes as a starting point. It then looks at the process of brand choice, more specifically the consideration set model and neurobiological concepts that support it. From there, it identifies three propositions, supported by neuroscience research, from which it deduces three branding laws. Finally, it briefly discusses these findings and draws several conclusions.

\section{THE CROSS-OVER BETWEEN BRANDING AND NEUROSCIENCE}

The aim of neuroscience is to understand the biological mechanisms that underlie mental activity. ${ }^{13}$ It seeks to comprehend how the neural circuits in our brain allow us to perceive the world around us (eg brand communication), recall that perception from memory and act on the memory of that perception. Neuroscience also studies the biological foundations of our emotional life. For instance, it seeks to determine how emotions influence our thinking and how the regulation of emotion, thought and action goes astray in diseases such as depression, mania, schizophrenia and Alzheimer's disease. ${ }^{13}$

The complexity of these issues are enormous and historically, neuroscientists have adopted one of two approaches to tackle them. The first is the reductionist strategy, which focuses on analysing the elementary units of the nervous system: a molecule, a cell or a circuit. This bottomup approach examines how neurons communicate with one another and how interconnections are created during devel- opment, and modified by experience, especially seen through the study of simple animals. The second approach is the holistic strategy, which studies the mental functions in vivo, in human beings and animals, in a top-down fashion-often using neuroimaging techniques—seeking to relate these behaviours to the higherorder features of large systems of neurons. Both avenues have had considerable successes. ${ }^{13}$

The interest in neurobiological findings is growing rapidly, far beyond the boundaries of the field. For instance, there is a growing range of studies that apply neuroscientific knowledge and techniques to marketing issues, with sometimes interesting results. For example, a study by Samanez Larkin et al. ${ }^{14}$ showed that the brain of older adults over 65 shows less activation as a result of the anticipation of losing money than youngsters between 19 and 27 . This may be caused by a reduced experience of negative emotions with age, an insight that might be relevant for financial advisors.

Knutson et al. ${ }^{15}$ presented respondents with cash and then recorded their brain activity using functional magnetic resonance imaging (fMRI) when confronting them with different combinations of products and prices-some of good value, others of unfair value. One finding was that the price of a product or service almost literally produces a pain response in the brain. The researchers inferred by these findings that credit cards may 'anaesthetise' consumers against the pain of paying. A credit card alleviates this pain by postponing the physical payment - thus decoupling the pain from the purchase moment. This explains the microeconomic anomaly that consumers tend to overspend and undersave when using credit cards instead of cash. 
Moll et al. ${ }^{16}$ found that altruistic behaviour, such as making a charitable donation, generates the same brain response as obtaining a financial reward and that altruism tied to abstract moral beliefs relies on parts of the brain that are uniquely developed in humans (ie the anterior prefrontal cortex). Such studies explain why we perform such acts, even though they provide no direct personal benefit and sometimes bear a personal cost. Findings like these can be of interest to fundraisers at NGOs and charities. It is easy to extend the list of examples.

Although the contributions of such studies are sometimes debated (see Rubenstein ${ }^{17}$ ), internationally accredited newspapers such as the Financial Times, The New York Times, The Wall Street Journal and Time have all featured articles on the results of such studies over the last few years, indicating public interest. Interestingly, though, these studies share the fact that they rely on the holistic route of investigation. Invariably, they make use of neuroimaging techniques to obtain data for their conclusions. It is fair to say that research in the reductionistic tradition, on the other hand, is underrepresented in the growing body of 'neuromarketing' literature, if not absent from it. ${ }^{18}$ This should be of little surprise. Human beings can be shown advertising campaigns or perform other tasks in experiments, but we cannot put their brain in a Petri dish under a microscope to study changes at the cellular and synaptic level caused by it without inflicting serious risks to their health. Given our current technical possibilities, it is difficult to obtain empirical neurobiological results on marketing issues from human subjects using reductionistic research designs.

At the same time, however, reductionistic research in neuroscience has resulted in an enormous leap in our knowledge of how learning takes place and how memory works. So much so that in 2000 , three neuroscientists-Arvid Carlsson, Paul Greengard and Eric Kandel-won the Nobel Prize for Medicine and Physiology for their work within the reductionist 'paradigm', especially on the signal transmission at the cellular level of the nervous system. ${ }^{19}$ Some writers, notably Bickle, ${ }^{20}$ even go so far as to state that all phenomena addressed by psychology and cognitive science will in the end be explained at the molecular level, eliminating more holistic explanations (see also Looren de Jong and Schouten $^{21}$ ). As many brand decisions are memory-based, ${ }^{7,22}$ the marketing literature and practice could potentially benefit from the reductionist body of knowledge. As Kandel ${ }^{23}$ writes, elementary forms of learning are common to all animals with an evolved nervous system. Hence, learning at the cell and molecular level can be studied effectively even in simple invertebrate animals. Therefore, this paper aims to integrate reductionistic findings where appropriate and obtain from them implications for branding, by deduction-which is the only valid option as the empirical route is unavailable. As neurobiology-both holistic and reductionstic-is an exact science, the insight into the principles of memory storage and retrieval it has established so far could help us to identify laws in branding.

\section{WHAT IS A BRAND AND WHAT IS BRANDING?}

In order to speak clearly about branding laws, however, we must first define what we mean when we talk about a 'brand' and about 'branding'. 


\section{Defining a brand}

For our purpose, we will adopt a definition in line with Franzen and Bouwman, ${ }^{24}$ and state that a brand is a network of associations with a (brand) name in the brain of a person. Brands, according to this view, are pieces of information, meanings, experiences, emotions, images, intentions, etc interconnected by neural links of varying strength.

The benefit of this definition is that it builds a bridge between branding and neuroscience, which is needed for our purpose. Brand associations are long known to influence consumer preference and behaviour. In the case of supermarkets, for example, research has shown a strong correlation between supermarket associations and supermarket choice. Woodside and Trappey ${ }^{25}$ have shown that the choice for a certain supermarket by consumers can be predicted on the basis of the associations people have in their minds about these places. Castleberry and Ehrenberg ${ }^{26}$ have pointed out that associations can show strong correlations with the market share of a brand. Also, numerous studies indicate that products from countries with certain associations are preferred above those produced in other nations - an observation known as the country-of-origin effect (see Verlegh ${ }^{27}$ and Peterson and Jolibert $^{28}$ ). In a neuroimaging study using fMRI, McClure et al. ${ }^{29}$ found that around half of their respondents selected Pepsi over Coke in a blind tasting test. Yet when given the choice, around three quarters of the respondents preferred Coke-despite similar or even slightly less liked taste. This latter preference correlated with strong activity, absent during the blind test, in the prefrontal cortex and the hippocampus - brain areas where our higher cognitive and memory functions reside.
McClure and colleagues gave respondents no information about the Coke and Pepsi brands before or during the experiment. This means that their differing brain responses must have been entirely the result of information stored in their long-term memory, evoked at the moment of decision-making.

The experiment thus illustrates the power of brand associations: functional preferences (taste) can be overridden by brand preferences, retrieved from longterm memory at the moment of choice, influencing the final decision in favour of one brand at the cost of another. This is of course exactly what marketers who are building brands aim for: creating consistent brand preference. The question is, then, whether delving deeper into the neuroscientific underpinnings of brand associations can reveal reliable principles or laws that marketers can follow for creating this kind of brand preference.

\section{Defining branding}

Our definition of branding will have to take note of associations as well. Therefore, we will define 'branding' as the activity by brand owners of associating the brand name with those pieces of information, meanings, emotions, images, intentions, etc that are of key importance in the decision-making process of customers and of stakeholders in general. ${ }^{30}$ More specifically, we define branding as establishing efficient, choice-shaping associations with the brand name (in the minds of members of a target group). This definition flows from the axiom that brands strive to be chosen and that branding as an activity, therefore, is aimed at increasing the likelihood that they are.

We must note that branding laws-in the sense discussed here-would only be applicable in situations wherein the brand 
choice is at least partially based on associations stored in long-term memory. Of course it is possible, at least in theory, that choice is not influenced at all by brand information stored in memory but is entirely stimulus-driven-for example in the case of new, unknown or unfamiliar brands or through some form of highly effective point of sale communication. By definition, we cannot attribute the choice for the brand in such 'perfect stimulusdriven' instances to associations in the customer's brain established by prior branding efforts. Such choices may be subject to principles of visual perception (see Lee $^{12}$ and Shindler and Berbaum ${ }^{31}$ ) or on-the-spot persuasion (see Cialdini ${ }^{32}$ ), but not to branding or branding laws based on associations as discussed here. In other situations, decisions are mixed (ie memory and stimulus-driven) in that they are founded on input from the environment as well as on information retrieved from memory. ${ }^{12}$ In the end, almost all brand choices are at least partially memorybased, ${ }^{7,22}$ and when long-term memory plays a role, branding laws might apply.

\section{THE PROCESS OF BRAND CHOICE}

The question is, then, whether or not neuroscience can help to identify regularities in the way branding can influence the outcome of memory-based choice situations. Before we can turn to answering this question, it is first necessary to look in some more detail at the choice process itself. One broadly accepted and wellresearched theory of the brand choice process, and one that draws considerable academic attention, is the consideration set model based on Howard and Sheth. ${ }^{33}$ It distinguishes between two conceptually different phases, ${ }^{34}$ namely that of evocation (in which a set of brands to choose from is recalled from long-term memory) and evaluation (in which the final choice is made). The basic premise is that people do not make a choice out of all the brands they are aware of but from a smaller subset called the consideration set, which is often (goal) constructed (see Paulssen and Bagozzi $\left.^{35}\right)$. Moreover, it seems that the consideration set is universal and found across national cultures. ${ }^{36}$

In order for a brand to be chosen, the consideration set model states that the brand must first be recalled from memory and then needs to be evaluated positively. It is important to note that in the majority of choice occasions, the largest part of this process may take place implicitlyproceeding outside of our conscious attention (see Coates et al. ${ }^{37}$ and Shapiro and Krishnan ${ }^{38}$ ). Much of human behaviour in general appears to be shaped by factors beyond our awareness. ${ }^{39}$ Bargh and Chartrand $^{40}$ estimate that roughly 5 per cent of the time, conscious deliberation plays a causal role in guiding our behaviour. Persaud et al. ${ }^{41}$ have elegantly proven experimentally that we can make correct decisions without knowing why or how we make them. What is more, unconscious thought can even lead to better, more satisfying decisions, especially in the case of more complex product choices such as deciding between houses or cars. ${ }^{42}$ Evocation, then, takes place largely outside our awareness-a position supported by neuroscience research, as we will see in a moment. Conscious evaluation, on the other hand, does take place of course, but especially in the case of high-involvement products and services (eg mortgages, cars, television sets, photo cameras, etc) and always after evocation, so that evocation is arguably the more fundamental activity. ${ }^{24}$

Our second axiom is, therefore, that whether or not a brand is evoked at the buying moment is a key determinant of the ultimate choice. This axiom is not 
random, but stems from a growing body of research and literature that emphasises 'brand saliency' as the dominant factor in final choice. ${ }^{11,24,38,43-48}$ Nedungadi, ${ }^{48}$ for example, has studied the phases of consideration and choice and has shown that brands that are more strongly associated with primary choice cues (ie brands that are more salient relative to those cues) have a higher chance of entering the consideration set and of being chosen. Brands that are recalled first are more likely to be chosen. Hence, we will state that branding exerts a crucial influence on choice by intimately connecting the brand name with primary choice cues.

The finding that saliency - in the sense of becoming top-of-mind at the moment of choice-is such a dominant factor in brand choice and is supported by recent findings in neuroscience. In an overview article, Duncan ${ }^{49}$ has shown that there is a very general principle at work in our brain under which stimuli compete for 'cortical representation'. Visual and auditory signals, for example, vie for our attention. There is a constant battle going on in our brain, whereby cues compete for entry into our awareness.

This principle of competition for awareness not only applies to external cues (eg visual or auditory stimuli coming from the environment) but also to thoughts, actions, goals, meanings and especially memories as well (eg cues emanating from inside the brain). Given the associative nature of memory, retrieving a goal-relevant memory (eg a brand name) often involves selecting it against several competing memories-a process sometimes called 'mnemonic competition'. 50 Only if a cue enters our awareness does it become available for report. ${ }^{51}$

Given that brands are networks of associations (see Franzen and Bouwman ${ }^{24}$ ), they must compete for cortical represen- tation as well, and the winner of this competition - the most 'salient brand'-is the most probable candidate for final choice (cf., Nedungadi ${ }^{48}$ for example). This latter finding is further supported by the fact that awareness competition is resolved, unconsciously, largely on the basis of relevance. ${ }^{49,50}$ This is much in line with the finding of Kahneman et al. ${ }^{52}$ and Kahneman and Ritov $^{53}$ that automatic affective valuation is the main determinant of many judgments and behaviours. Damasio's $^{54}$ somatic marker theory proposes a similar automatic evaluation of choice options, explicitly based on bodily sensations-although this latter aspect has been challenged, for instance by Rolls. ${ }^{55}$ Our view of the brand choice process resembles Kahneman's ${ }^{56}$ System 1 process of intuitive judgment, in that brand choice takes place largely outside our consciousness and is rapid, automatic and effortless.

\section{INCREASING A BRAND'S CORTICAL REPRESENTATION PROBABILITY}

Against this background, we can begin to formulate several propositions that lay the foundation for the deduction of branding laws. So far, we have assumed that brands want to be chosen and that branding is focused on increasing the probability that they are. More specifically, branding aims to influence choice behaviour by maximising the probability that the brand wins the (unconscious) competition for cortical representation - the battle for awareness. ${ }^{57}$ Linking the brand to primary choice cues is paramount in achieving this. ${ }^{11,48}$

Rephrased in neurological terms, this means that branding seeks to increase the likelihood that the neuron-assembly or association network that represents the brand is activated and the brand name enters our awareness during the choice 
process. Thus, we are interested in the neurological rules that determine what we will call a brand's cortical representation probability. Once established, such rules would give rise to branding laws that point towards actions we can take to increase the brand's cortical representation probability and hence the chance it is chosen.

\section{CORTICAL REPRESENTATION PROPOSITIONS}

Brands with a high cortical representation probability can be called 'strong' brands because, as we have seen, they are the most salient and hence have the largest influence on choice. We will now formulate three propositions about the brain that govern a brand's cortical representation probability and hence strength: the relevance, coherence and richness theses.

\section{Proposition 1: The Relevance Thesis. The relevance thesis says that the cortical representation prob- ability of an associa- tion network (brand) depends on the degree to which it is connected with elements that are of personal importance in the choice process (ie 'salient choice cues').}

The degree to which brand information is of personal relevance to us strongly influences the degree to which this information is stored in long-term memory and the ease with which it can be retrieved from it. Neurobiological studies show that relevant or emotionally charged phenomena are better remembered than irrelevant and neutral events. ${ }^{58,59}$ For example, biologically significant information about food or sex is stored more durably than insignificant information. ${ }^{58}$
(Thus, there appears to be some truth in the old advertising adage that 'sex sells'.) Montague $^{60}$ states that brands are relevant to the degree to which they create biological or psychological reward signals in our brains that activate the dopamine system (which is involved in creating feelings of pleasure and motivation). In an fMRI study of remembering word pairs, Kuhl et al..$^{50}$ showed that the brain chooses to remember elements it thinks are most relevant to certain tasks and suppresses less relevant cues. Bartsch et al. ${ }^{61}$ have found that long-term memory formation requires, among others, the inactivation (or switchingoff) of memory 'suppressors' that provide a threshold for memory formation. These suppressors ensure that only salient features are learned and thus allow for emotions to modulate memory storage. ${ }^{23}$ In other words, relevance relieves suppression, thus facilitating long-term memory formation.

Duncan $^{49}$ and others have demonstrated that the competition for cortical representation is 'biased' towards elements that are relevant for our situation or task. The higher the relevance of an element, the higher the chance it wins the battle for awareness. Brands that are linked to what is significant for their customers or stakeholders at the moment of decision (their 'primary, salient choice cues') have a higher chance of being evoked, of entering our awareness and of being chosen (cf. Holden and Lutz, ${ }^{11}$ Nedungadi ${ }^{48}$ and Wells and Fallon ${ }^{62}$ ). Research shows further that elements with identical features engage in a more vigorous mutual competition for awareness. That is, they repress each other forcefully and this reduces their combined inhibitory effect on a more distinctive cue. As a result, the distinctively relevant brand will be activated more strongly, increasing the probability that it will enter our awareness and receive our attention (see Duncan ${ }^{49}$ and 
Yantis $\left.^{51}\right)$. The imperative for brands, therefore, is to be distinctively relevant.

The actual choice cues used by customers can vary between individuals and for the same individual between different occasions. ${ }^{11,43}$ Moreover, as these primary choice cues differ per product or service category and per situation, brands only have a high cortical representation probability relative to a certain category or use occasion. Brand strength is therefore category and situation-relative. It is important to note that it seems plausible that choice cues are not necessarily a given, but that brands may be able to influence them. There is practical evidence for example that Nike was able to transform the sneaker category, by consistently communicating a spirit of 'irreverence'. Today, such a mentality seems relevant for a broad group of consumers whereas in the 1980s all that counted to its narrow client base was the ability to produce a good professional running shoe (see, eg Bedbury and Fenichell ${ }^{63}$ ).

Proposition 2: The Coherence Thesis. The coherence thesis states that the likelihood that a neuron or association network (ie brand) will win the battle for awareness is proportional to the number of times its connections with cells or association networks that are fired during the choice process (ie choice cues) have been activated in the past. The most efficient way to externally induce these 'past firings' is by repeating a (brand) message that is specific.
The coherence thesis is based on a cornerstone of our current neurobiological understanding of memory (see Matynia et al. ${ }^{64}$ ). Coherence has two components: repetition and specificity. First, it was long an important hypothesis in the neuroscience community that when one neuron A repeatedly or persistently takes part in firing another $B$, the efficiency of $A$ in firing $\mathrm{B}$ increases. This is so, it was thought, because repeated firing between $A$ and $B$ causes a long-term strengthening of the synapses between the two neurons. ${ }^{65}$ Bliss and Lømo ${ }^{66}$ were the first to confirm this phenomenon, called 'long-term potentiation' (LTP), through research. They found that repetition makes the communication between synapses more efficient and leads to a higher excitability of the cells involved. Kande ${ }^{23}$ and others later found that repetition and the resulting longterm potentiation are the foundation of the process of memory. More specifically, conversion of a transient memory into a longer-term memory requires 'spaced' repetition of that memory. This is true for primitive life-forms as well as for higher vertebrates and humans. As Kandel ${ }^{23}$ writes: 'Practice makes perfect-even in snails'. Repeated activation of one memory also weakens competing memories, thus facilitating the retrieval of repeated memories over nonrepeated memories. ${ }^{50}$ Phenomena such as "flashbulb' memories, in which very significant one-time personal events seem to etched into memory (eg Kristallnacht experience, witnessing the JFK assassination, our own wedding, etc), and the 'famous overnight effect', in which people mistakenly think that a presented name they have seen only once before belongs to a famous person, do not contradict this. ${ }^{67-70}$

Secondly, empirical studies show that the more identical the stimulus (eg the brand's message or the choice cue) is to 
the stimulus stored in memory, the more likely the memory can be activated and retrieved ${ }^{71,72}$ (see, eg Tulving and Thomson $^{72}$ and Vaidya et al. ${ }^{73}$ ). This means that the more specific the brand's message over time, the more likely the original synaptic connections are reactivated and hence strengthened-thus improving the brand's cortical representation probability and its chance of being selected.

The consequence for branding is that brands seeking to be chosen must constantly strengthen their links with customers' or stakeholders' choice criteria by reactivating them. Even though choice criteria may vary across categories and situations, coherence in the branding policy is compulsory from a neurological standpoint. In order to reactivate certain connections, the triggering stimulus must be as specific as possible over time and across 'touch points' (eg ads, campaigns, products, personnel, stores, websites, etc). Coherence, in other words, means repeated specificity.

Proposition 3: The Richness Thesis. The richness thesis states that the likelihood that a neuron or cell assembly (ie brand) will be activated is proportional to the number of direct links it has with cells or cell assemblies that are activated during the choice process (ie cues).

Ebbinghaus $^{74}$ showed that the chance of activation of a neuron B, by a neuron A, decreases with the number of intervening neurons between A and B. This means, generally stated, that the more incoming (dendritic) links a cell or cell assembly, B, has that are directly connected with often activate cell assemblies (ie cues), the more likely B will be activated. We will call this degree of synaptic connectedness the 'richness' of the network.

In principle, every connection with the choice cue can potentially activate the brand's network. The more connections there are, the higher the likelihood that the whole network is evoked forcefully. The likelihood that individual neurons pass on a signal depends on the summation of the signals coming in. Generally, more signals make a higher sum. ${ }^{75}$

In case more than one choice cue is used to evoke brands, which may often be the case, the 'net sum' of excitatory signals will be higher in a richer network. This effect is further amplified if the elements of the network are also mutually interconnected, as this facilitates further activation cascades in an exponential fashion. This higher 'net sum' of excitatory signals results in a more forceful activation of the brand name - a phenomenon sometimes referred to as 'bottom-up stimulus strength'(see Dehaene et al. ${ }^{76}$ ). Stronger activation increases the chance that the brand wins the competition for cortical representation when two or more brands are cued simultaneously and engage in a mutually inhibitory battle for awareness (see Duncan, ${ }^{49}$ Yantis ${ }^{51}$ and Dahaene et $\left.a .^{76}\right)$.

Research shows that such richer association networks (ie higher numbers of synaptic links) are formed as a result of richer environments. ${ }^{77,78}$ Virtual reality environments are used, for example, to rehabilitate the memory performance of (elderly) people. ${ }^{79}$ Environments are richer when they provide higher quantities of relevant stimulation, for example more opportunities for play, exercise, learning, social interaction, physical activity, etc. ${ }^{80,81}$ Such environments present more stimuli and induce more 
elaborate processing by arousing curiosity and stimulating exploratory behaviour or creating engagement, generally leading to rapid increases in synaptic connectivity (ie formation of new synapses and increase of synaptic density) and improved memory performance. ${ }^{78,82,83}$ There is much evidence that environmental enrichment can delay memory degeneration ${ }^{77}$ and can sometimes repair memory deficits $^{78,83}$ even after severe neuronal and synaptic loss due to neurodegenerative diseases. ${ }^{84}$

The branding consequence of the richness thesis is that brands seeking to be chosen must not only create strong links between their customers' choice criteria and the brand and interconnections between the other elements of the brand's association network but also create as many of these (inter)connections as possible. They must seek to create a rich network of internal and external synaptic links. ${ }^{85-87}$ Contacting customers in 'richer brand environments' does this. In practice, this means using more engaging and intriguing communication forms and richer, more immersive communication media. One example of an engaging, participatory brand environment is toy manufacturer Lego's experience store in Orlando, Florida, USA and other places around the world. The designers created play spaces in the middle of the stores and dozens of cylinders containing the Lego bricks for grabs, thus encouraging a direct experience of its products instead of creating a passive display of closed boxes on long shelves.

In sum, the three theses provide a neurological branding maxim: create as many synaptic connections as possible (richness) between the neural representations of primary choice cues and the brand name (relevance), and reactivate these connections regularly through a specific message (coherence).

\section{COROLLARIES: THREE BRANDING LAWS}

From the propositions above, we can now infer three branding laws as corollaries. They are the laws of distinctive relevance, coherence and participation. Whereas the three theses refer to robust characteristics of how the brain works, the three laws deduced from them stipulate what the aims of branding activities must be to act in accordance with these brain characteristics. How these aims are then actually reached in practice is a topic in itself, and is beyond the scope of this paper.

As the three laws are neurologically founded, they possess a strong regularity that turns them into branding prerequisites. As stated in the introduction, these laws are no new discoveries. They are used, in varying degrees, as rules of thumb. This paper argues, however, that their status must be raised to a higher level of importance and reliability. Seen from a neurological standpoint, they should be treated and followed as universal branding laws with a scientific foundation.

Law 1: The higher the distinctive relevance of branding efforts, the more likely the brand will be chosen.

Increasing the probability a brand is chosen requires associating it more strongly and uniquely with elements that are of personal significance to the customer at the moment of decision-making (ie primary choice cues). This is the law of distinctive relevance. An element is relevant to the degree it is used by customers as a cue for activating brand names at the moment of choice and for evaluating brand performance.

Brands may also be able to influence the cues people use. Empirical evidence shows that what is relevant for customers 
can vary between individuals and, for the same individual, between different occasions. Typically, however, primary choice cues include product category, sub-category, functional and symbolic attributes, use occasion, self and user image and combinations of these. ${ }^{11,24,43}$ The brand's core message and its propositions must be built around and distinguished within the range of cues that are important to customers in the specific environment the brand operates in.

Law 2: The higher the coherence of branding efforts across time and space, the more likely the brand will be chosen.

Ensuring a front position in the consideration set requires repetition of a specific, relevant core message for the brand. This is the law of coherence. Coherence equals repetition multiplied by specificity $(\mathrm{c}=\mathrm{r} . \mathrm{s})$. Repetition is needed to create strong synaptic connections with choice criteria, which in turn is required for increasing cortical representation probability, which in turn is required for becoming top of mind at the moment of choice. Specificity is necessary because specific messages are much more likely to repeatedly reactivate the same connections and hence strengthen them-thus improving the brand's cortical representation probability. Moreover, communicating many messages at the same time or in subsequent campaigns over the years creates confusion at best and contradiction at worst, resulting in negative emotions such as aversion and dissonance (cf. Festinger ${ }^{88}$ ). Negative emotions may produce a cascade of inhibitory signals across the association network, thus decreasing the probability that the brand is activated and evaluated positively. Even if such a brand is strongly activated, we note that in the competition for awareness and a top position at the choice moment, it is at a disadvantage versus brands that are less or not at all impeded by inhibiting and memory-repressing inconsistencies (see Duncan ${ }^{49}$ ).

Coherence in branding policy through time and space (ie across physical touch points such as advertising, point-of-sale materials, products, new product development, packaging, websites, etc) is compulsory from a neurological standpoint. In contrast, incoherence is a recipe for diminishing the brand's chance of being chosen and for destroying its financial value. Incoherence (whether purposefully, unintentionally or through the lack of leadership) is a 'Bonsai' strategy. It keeps the brand small compared to its actual market potential (like the Japanese art of tree miniaturisation).

It may seem from this account that sticking to one theme is all a brand has to do. There is a difference, however, between the laws (branding aims) and the particular way in which one adheres to them in practice (branding activities). For example, in practice, repetition must be combined with the opposite need for change, to maintain curiosity and prevent people from becoming bored by the brand. This is done, for example, through creating surprise and presenting the same brand message in ever-evolving interpretations, forms and expressions. This then puts a premium on high 'brand orientation' and rich brand concepts that can act as long-term 'business hubs' (cf. Gromark et al. ${ }^{89}$ ). Coherent change and variation around one brand theme (which only a rich brand concept allows) provides additional reinforcement of the brand's cortical representation probability, because it draws more attention and induces more active processing ('elaboration'), both of which increase memory performance. $^{23,90,91}$ 
Similarly, specificity must be combined with the opposite need for broadness. After all, strong brands become more profitable when they are successfully leveraged into other categories. ${ }^{92}$ Of course, surprise and broadness must be created without compromising repetition and specificity (ie coherence), which is precisely what Van der Vorst, ${ }^{93,94}$ Loken and Roedder ${ }^{95}$ and others have shown.

Law 3: The more engaging the branding environment that is created, the more likely the brand will be chosen.

To win the battle for awareness, brands must create as many synaptic connections as possible between choice criteria and the brand name and within their own association network. We call this a rich network of synaptic links. Richer association networks are formed in the brain as a result of richer, participatory environments that induce a more elaborate or a more comprehensive processing of brand stimuli. Richer environments are settings with a higher propensity to arouse curiosity and to create engagement and participation.

Brands that induce motivated attention by making us curious or by better tempting their customers to try, play, practice, learn, exercise, adapt, interact or socialise with them are more likely to win the battle for awareness and be chosen. This is the law of participation. Again, there are many ways in which brands can create participation in practice. The law of participation does not stipulate what way should be chosen; it merely states that brands creating participation (in whichever way) increase their chance of being chosen. For instance, brands may seek to reach customers with richer media and more intriguing, engaging forms that create interaction, involvement and dialogue (within constraints such as brand fit, budget, reach, etc). In practice, brands must develop a participation strategy that balances richness with reach (the number of people contacted), as richness and reach often form a trade-off (cf. Evans and Wurster $^{96}$ ).

\section{DISCUSSION}

It is beyond the scope of this paper to discuss all implications of these three branding laws for the practice of branding. In general, however, it is useful to distinguish between the three theses (describing brain characteristics), the three laws (describing branding aims) and branding activities (things done by marketers to act in accordance with the laws). This paper has focused on the first two. Several final remarks may be made about the laws.

\section{Remarks on the law of distinctive relevance}

Regarding the first law, at least two things can be noted. We have seen that winning the competition for entry into customers' awareness is crucial for any brand. This selection process takes place largely outside our consciousness and is rapid, automatic and effortless (see Kahneman ${ }^{56}$ ). This means that it is crucial to study how efficiently brands are evocated by customers' primary choice cues, instead of focusing exclusively on brand evaluation. Moreover, if evaluation takes place it is happening only after evocation. This may require changes in standard research designs.

Operationalising brand awareness: First, in the majority of commercial tracking studies, the focus seems to be on the product category as the only cue for measuring brand saliency (generally called 'top-of-mind awareness'). Empirical evidence suggests, however, that people 
use many more cues for recalling brands. It is important that the operationalisation of brand awareness is broadened, by not only measuring it relative to the product category but also against other primary choice cues. $^{43}$

Measuring relevance: Secondly, when measuring brand relevance the focus is generally on brand image. That is, the brand to attribute connection is often measured, which is important in the evaluation phase. What is often neglected is the attribute to brand connection, which is crucial for evocation and the likelihood of entering customer's consideration sets (cf. Holden and Lutz ${ }^{11}$ ). Research designs should start to incorporate this. ${ }^{43}$

\section{Remarks on the law of coherence}

Maintaining coherence: Regarding the second law one can observe that in practice, coherence is often sacrificed due to short-term economic pressures (see, eg Lodish and Mela ${ }^{97}$ ). It seems that marketers often fail to understand or nurture the brand's deeper identity. Following the craze of the day, sending conflicting 'interim' messages for sales purposes or extending the brand with non-fitting new products and services are common causes that kill repetition and specificity. Thus, the major setbacks in a brand's long-term quest of being chosen are often selfinflicted handicaps created by discontinuity, brand dilution and wavering leadership. While we may increase quarterly sales, 'short-termism' can foster a tendency for the brand to grow weaker, thus amplifying short-term sales pressures in the future and creating a vicious circle. The second law invokes the repeatsurprise and the specificity-broadness trade-offs, and the need to combine these opposing goals (cf. Walvis ${ }^{98}$ and Collins and Porras ${ }^{99}$.

\section{Remarks on the law of participation}

Participation is often neglected: Regarding the third law, we can observe in practice that richness and participation are often not a focal point in media policy. The traditional focus of most media agencies and advertisers is on Gross Rating Points (a common measure of the average percentage of target group members contacted in a certain period) and hence on reach. As more reach means lower richness (cf. Evans and Wurster ${ }^{96}$ ), conventional media selection unwittingly sacrifices brand saliency and hence long-term brand sales. The third branding law creates the imperative of optimising the richness-reach trade-off. Within the set of feasible media, richness and reach must be mutually served (of course given constraints such as medium fit with the brand concept, budget, media prices, etc).

\section{CONCLUSIONS}

Brands seek to be chosen by customers, and branding as an activity is aimed at increasing the probability that they are. In order to reach this goal, brands must win the unconscious battle for awareness during the process of consideration set formation and choice. Brands that win the battle for awareness (ie the most salient brands) are more likely to be chosen. Based on neuroscientific insights, brands following the three branding laws discussed in this paper have a higher chance of winning the competition for cortical representation and hence choice than a brand that does not. They are the laws of distinctive relevance, coherence and participation. In one sentence, the motto of these laws is: creating and repeating relevant specificity (over time and across touch points) around one central brand theme, using the richest and most engaging forms and media possible. This then is a general requirement 
for an effective allocation of marketing investments. Stated slightly more pragmatically in the form of key questions, the three laws of branding require that one asks of every branding act:

- Is it distinctively relevant?

- Is it a specific expression of the brand theme?

- Is it delivered in the most engaging form possible?

The above account and the deduction of the three laws is an attempt to add to and elaborate upon existing work, to establish a stronger foundation for the field and to translate insights from neuroscience into empirical consequences for the activity of branding. It adds to a synthesis of disciplines in which branding provides a framework of questions for which neuroscience could provide an insight into the biological underpinnings. The main purpose of this paper has been to draw attention to the idea that the proper status of three branding principles known to most practitioners (distinctive relevance, coherence and participation) is not recognised and should be raised to a higher level: that of laws.

The branding law theorem is open for further research, to fill in blanks, refine and elaborate upon the above material, quite possibly to uncover more laws, etc. If strong brands are more valuable at the stock exchange $e^{3,100}$ and the three branding laws explain how to create such brands, then the theorem bears promise. With today's rapid advances in neuroscience, it may be possible in the coming years to ever more tightly link the micro level of the customer's mental world (where neural associations can be influenced by marketers) to the macro level of companies' financial success and their share prices on the stock exchange.
It may also mean that in the future, marketing directors are not only judged by the results they deliver but also by the degree to which they have followed the laws of their profession in the process. These laws hint at the results one could and therefore should have obtained, thus providing a new type of benchmarks. This may improve the effectiveness of marketing investments and may prove to be a leap forward for the professionalism of our field.

\section{Acknowledgment}

The article is the inspiration for the book 'Three Laws of Branding' by the same author, forthcoming in the fall of 2008 .

\section{References}

(1) Millward Brown, O. (2007) 'Brandz:Top 100 most powerful brands', Millward Brown, London.

(2) Interbrand - BusinessWeek. (2007) 'Best Global Brands 2006: A Ranking By BrandValue', Interbrand, London.

(3) Madden, T. J., Fehle, F. and Fournier, S. M. (2006) 'Brands matter: An empirical demonstration of the creation of shareholder value through branding', Journal of the Academy of Marketing Science, Vol. 34, No. 2, pp. 224-235.

(4) Alsop, R. J. (2004) 'The 18 Immutable Laws of Corporate Reputation: Creating, Protecting, and Repairing Your Most Valuable Asset', The Free Press, New York.

(5) Ries, A. and Ries, L. (2002) 'The 22 Immutable Laws of Branding: How to Build a Product Or Service Into a World-Class Brand', Harper Collins Publishers, New York.

(6) Blaug, M. (1992) 'The Methodology of Economics or How Economists Explain', Cambridge University Press, Cambridge.

(7) Lynch, J. G. and Srull, T. K. (1982) 'Memory and attentional factors in consumer choice: Concepts and research methods', Journal of Consumer Research, Vol. 9, No. 1, pp. 18-37.

(8) Bettman, J. R. (1986) 'Consumer psychology', Annual Review of Psychology, Vol. 37, pp. 257-289.

(9) Fazio, R. H. (1986) 'How do attitudes guide behavior', in Sorrentino, R. M. and Higgins, E. T. (eds.) 'Handbook of Motivation and Cognition: Foundations of Social Behavior', Guilford Press, New York, NY, pp. 204-243. 
(10) Nedungadi, P. and Hutchinson, J. W. (1985) 'The prototypicality of brands: Relationships with brand awareness, preference and usage', in Hirschman, E. C. and Holbrook, M. B. (eds.) 'Advances in Consumer Research', Association for Consumer Research, Provo, UT,Vol. 12, pp. 498-503.

(11) Holden, S. J. S. and Lutz, R. J. (1992) 'Ask not what the brand can evoke: Ask what can evoke the brand', Advances in Consumer Research, Vol. 19, No. 1, pp. 101-107.

(12) Lee, A.Y. (2002) 'Effects of implicit memory of memory-based versus stimulus-based brand choice', Journal of Marketing Research, Vol. 39, No. 4, pp. 440-454.

(13) Albright, T. D., Jessell, T. M., Kandel, E. R. and Posner, M. I. (2000) 'Neural science: A century of progress and the mysteries that remain', Cell, Vol. 100, Neuron, Vol. 25, pp. S1-S55.

(14) Samanez Larkin, G. R., Gibbs, S. E. B., Khanna, K., Nielsen, L., Carstensen, L. L. and Knutson, B. (2007) 'Anticipation of monetary gain but not loss in healthy older adults', Nature Neuroscience, Vol. 10, No. 6, pp. 787-791.

(15) Knutson, B., Rick, S., Elliott Wimmer, G., Prelec, D. and Loewenstein, G. (2007) 'Neural predictors of purchases', Neuron, Vol. 53, No. 1, pp. $147-156$.

(16) Moll, J., Krueger, F., Zahn, R., Pardini, M., de Oliveira-Souza, R. and Grafman, J. (2006) 'Human fronto-mesolimbic networks guide decisions about charitable donation', Proceedings of the National Academy of Sciences USA, Vol. 103, No. 42, pp. 15623-15628.

(17) Rubenstein,A. (2006) 'Discussion of 'behavioral economics", in Blundell, R., Newey, W. K. and Persson, T. (eds.) 'Advances in Economics and Econometrics: Theory and Applications, Ninth World Congress-Volume II', Cambridge University Press, Cambridge, pp. 246-254.

(18) An extensive literature search by the author for this paper, in journals such as Nature, Science, Cell, Neuron, etc returned no reductionistic studies pertaining to marketing issues.

(19) Ungerstedt, U. (2000) 'Presentation speech', The Nobel Prize in Physiology or Medicine 2000, The Nobel Foundation.

(20) Bickle, J. (2003) 'Philosophy and Neuroscience: A Ruthlessly Reductionist Account', Kluwer Academic, Dordrecht, The Netherlands.

(21) Looren de Jong, H. and Schouten, M. K. D. (2005) 'Ruthless reductionism: A review essay of John Bickle's philosophy and neuroscience: A ruthlessly reductive account', Philosophical Psychology, Vol. 18, No. 4, pp. 473-486.

(22) Alba, J. W., Hutchinson, J. W. and Lynch Jr, J. G. (1991) 'Memory and decision making', in Robertson, T.S. and Kassarijian, H.H. (eds.) 'Handbook of Consumer Behavior', PrenticeHall, Englewood Cliffs, New Jersey, pp. 1-49.
(23) Kandel, E. R. (2001) 'The molecular biology of memory storage: A dialogue between genes and synapses', Science, Vol. 294, No. 5544, pp. 1030-1038.

(24) Franzen, G. and Bouwman, M. (2001) 'The Mental World of Brands: Mind, Memory and Brand Success', Oxfordshire World Advertising Research Centre.

(25) Woodside, A. G. and Trappey, R. J. (1992) 'Finding out why customers shop your store and buy your brand: Automatic cognitive processing models of primary choice', Journal of Advertising Research, Vol. 32, No. 6, pp. 59-78.

(26) Castleberry, B. S. and Ehrenberg, A. S. C. (1990) 'Brand usage: A factor in consumer beliefs', Market Research, Vol. 27, No. 4, pp. 477-484.

(27) Verlegh, P. W. J. (2001) 'Country-of-origin effects on consumer product evaluations', Doctoral Thesis, Wageningen University.

(28) Peterson, R. A. and Jolibert, A. J. P. (1995) 'A meta-analysis of country-of-origin effects', Journal of International Business Studies, Vol. 26, No. 4, pp. 883-900.

(29) McClure, S. M., Li, J., Tomlin, D., Cypert, K. S., Montague, L. M. and Montague, P. R. (2004) 'Neural correlates of behavioural preference for culturally familiar drinks', Neuron, Vol. 44, No. 2, pp. 379-387.

(30) We will use the term 'customers' in the remainder of the text, but note that our conclusions not only apply to customers and buying situations but more generally to all stakeholders and their brand decision-making situations.

(31) Shindler, R. M. and Berbaum, M. (1982) 'The influence of salience on choice', Advances in Consumer Research, Vol. 10, pp. 416-418.

(32) Cialdini, R.B.(1984) 'Influence:The Psychology of Persuasion', William Morrow and Company, New York.

(33) Howard, J. A. and Sheth, J. N. (1969) 'The Theory of Buyer Behavior', John Wiley \& Sons, New York.

(34) Ballantyne, R., Warren, A. and Nobbs, K. (2006) 'The evolution of brand choice', Journal of Brand Management, Vol. 13, No. 4/5, pp. 339-352.

(35) Paulssen, M. and Bagozzi, R. P. (2005) 'A selfregulatory model of consideration set formation', Psychology \& Marketing, Vol. 22, No. 10, pp. 785-812.

(36) LeBlanc, R. P. and Herndon Jr, N. C. (2001) 'Cross-cultural consumer decisions: Consideration sets-A marketing universal', Marketing Intelligence \& Planning, Vol. 19, No. 7, pp. 500-506.

(37) Coates, S. L., Butler, L.T. and Berry, D. C. (2004) 'Implicit memory: A prime example for brand consideration and choice', Applied Cognitive Psychology, Vol. 18, No. 9, pp. 1195-1211. 
(38) Shapiro, S. and Krishnan, H. S. (2001) 'Memorybased measures for assessing advertising effects: A comparison of explicit and implicit memory effects', Journal of Advertising, Vol. 30, No. 3, pp. 1-13.

(39) Loewenstein, G. (1996) 'Out of control:Visceral influences on behavior', Organizational Behavior and Human Decision Processes, Vol. 65, No. 3, pp. 272-292.

(40) Bargh, J. A. and Chartrand, T. L. (1999) 'The unbearable automaticity of being', American Psychologist, Vol. 54, No. 7, pp. 462-479.

(41) Persaud, N., McLeod, P. and Cowey, A. (2007) 'Post-decision wagering objectively measures awareness', Nature Neuroscience, Vol. 10, No. 2, pp. 57-261.

(42) Dijksterhuis, A. P., Bos, M. W., Nordgren, L. F. and van Baaren, R. B. (2006) 'On making the right choice: The deliberation-without-attention effect', Science, Vol. 311, No. 5763, pp. 1005-1007.

(43) Romaniuk, J. and Sharp, B. (2004) 'Conceptualizing and measuring brand salience', Marketing Theory, Vol. 4, No. 4, pp. 327-342.

(44) Chandon, P. and Wansink, B. (2002) 'When are stockpiled products consumed faster? a convenience-salience framework of postpurchase consumption incidence and quantity', Journal of Marketing Research, Vol. 39, No. 3, pp. 321-335.

(45) Keller, K. L. (1998) 'Strategic Brand Management: Building, Measuring, and Managing Brand Equity', Prentice-Hall, New Jersey.

(46) Ehrenberg, A., Barnard, N. and Scriven, J. A. (1997) 'Differentiation or salience', Journal of Advertising Research, Vol. 37, No. 6, pp. 7-14.

(47) Holden, S. J. S. (1993) 'Understanding brand awareness: Let me give you a C(1)ue', Advances in Consumer Research, Vol. 20, No. 1, pp. 383-388.

(48) Nedungadi, P. (1990) 'Recall and consumer consideration sets: Influencing choice without altering brand associations', Journal of Consumer Research, Vol. 17, No. 3, pp. 263-276.

(49) Duncan, J. (2006) 'Brain mechanisms of attention', EPS Mid-Career Award 2004, The Quarterly Journal of Experimental Psychology, Vol. 59, No. 1, pp. 2-27.

(50) Kuhl, B. A., Dudukovic, N. M., Kahn, I. and Wagner, A. D. (2007) 'Decreased demands on cognitive control reveal the neural processing benefits of forgetting', Nature Neuroscience, Vol. 10, No. 7, pp. 908-914.

(51) Yantis, S. (2005) 'How visual salience wins the battle for awareness', Nature Neuroscience, Vol. 8, No. 8, pp. 975-977.

(52) Kahneman, D., Ritov, I. and Schkade, D. (1999) 'Economic preferences or attitude expressions? An analysis of dollar responses to public issues', Journal of Risk and Uncertainty, Vol. 19, No. 1-3, pp. 203-235.
(53) Kahneman, D. and Ritov, I. (1994) 'Determinants of stated willingness to pay for public goods: A study in the headline method', Journal of Risk and Uncertainty, Vol. 9, No. 1, pp. 5-37.

(54) Damasio, A. R. (1994) 'Descartes' Error: Emotion, Reason, and The Human Brain', Putnam Publishing, New York.

(55) Rolls, E. T. (1999) 'The Brain and Emotion', Oxford University Press, Oxford.

(56) Kahneman, D. (2003) 'Maps of bounded rationality: Psychology for behavioral economics', The American Economic Review, Vol. 93, No. 5, pp. 1449-1475.

(57) In case of high-involvement brands for which conscious evaluation takes place, attributes that are deemed important must be linked to it so that the brand can activate them as Holden and Lutz $^{11}$ point out (ie 'the brand-to-cue link'). In other words, in this case not the brand name but specific attributes must enter our awareness. The same rules and laws that govern the cortical representation probability of brands will also guide the cortical representation probability of attributes (cf. Duncan ${ }^{49}$ ). Therefore, we will not treat this topic separately.

(58) Paz, R., Guillaume Pelletier, J., Bauer, E. P. and Paré, D. (2006) 'Emotional enhancement of memory via amygdaladriven facilitation of rhinal interactions', Nature Neuroscience, Vol. 9, No. 10, pp. 1321-1329.

(59) Canli, T., Zhao, Z., Brewer, J., Gabrieli, J. D. E. and Cahill, L. (2000) 'Event-related activation in the human amygdala associates with later memory for individual emotional experience', The Journal of Neuroscience, Vol. 20, No. 19, RC 99 , pp. 1-5.

(60) Montague, R. (2006) 'Why Choose This Book?-How We Make Decisions', Dutton, New York.

(61) Bartsch, D., Ghirardi, M., Skehel, P. A., Karl, K. A., Herder, S. P., Chen, M., Bailey, C. H. and Kandel, E. R. (1995) 'Aplysia CREB2 represses long-term facilitation: Relief of repression converts transient facilitation into long-term functional and structural change', Cell, Vol. 83, No. 6, pp. 979-992.

(62) Wells, D. G. and Fallon, J. R. (2000) 'Dendritic mRNA translation: Deciphering the uncoded', Nature Neuroscience, Vol. 3, No. 11, pp. 1062-1064.

(63) Bedbury, S. and Fenichell, S. (2002) 'A New Brand World: Eight Principles for Achieving Brand Leadership in the 21st Century', Viking Penguin, New York.

(64) Matynia,A., Kushner, S. A. and Silva, A. J. (2002) 'Genetic approaches to molecular and cellular cognition: A focus on LTP and learning and memory', Annual Review of Genetics, Vol. 36, pp. $687-720$. 
(65) Hebb, D. O. (1949) 'The Organization of Behavior: A Neuropsychological Theory', Wiley-Interscience, New York.

(66) Bliss, T.V. P. and Lømo, T. (1973) 'Long lasting potentiation of synaptic transmission in the dentate area of the anaesthetized rabbit following stimulation of the perforant path', Journal of Physiology, Vol. 232, No. 2, pp. 331-356.

(67) Sharot et al. ${ }^{68}$ add new evidence to the existing finding that flashbulb memories are not necessarily remembered with a higher objective accuracy. Instead, they find that strong emotions associated with the original event enhance the subjective, reported feeling of remembering.

(68) Sharot, T., Delgado, M. R. and Phelps, E. A. (2004) 'How emotion enhances the feeling of remembering', Nature Neuroscience, Vol. 7, No. 12, pp. 1376-1380.

(69) Based on the principle of LTP, repeated association of the brand name with a primary choice cue increases the probability the brand wins the competition for awareness (and thus choice) when evoked by this choice cue. This may seem to be contradicted by the 'famous overnight effect'. ${ }^{70}$ This effect refers to the finding that after a 24-hour delay between reading a list of nonfamous names and making fame judgments, nonfamous names were more likely to be mistakenly judged as famous than they would have been had they not been read earlier. The names became famous overnight. Upon closer inspection, however, this effect is not based on cued evocation (ie spontaneous recall) of brand names but on recognition of a name from a presented list (ie aided recall). It is not clear, however, that improving aided recognition would necessarily improve a brand's spontaneous recall, thus helping it win the competition for cortical representation when the brain activates a primary choice cue.

(70) Jacoby, L. L., Kelley, C., Brown, J. and Jasechkjo, J. (1989) 'Becoming famous overnight: Limits on the ability to avoid unconscious influences of the past', Journal of Personality \& Social Psychology, Vol. 56, No. 3, pp. 326-338.

(71) According to the 'encoding specificity principle', the target item (eg brand attributes) must be encoded in reference to the cue for the cue to be effective. ${ }^{72}$ The brand's message, therefore, must emulate the choice cues stakeholders use to evoke brands.

(72) Tulving, E. and Thomson, D. M. (1973) 'Encoding specificity and retrieval processes in episodic memory', Psychological Review, Vol. 80, No. 5, pp. 352-373.

(73) Vaidya, C. J., Zhao, M., Desmond, J. E. and Gabrieli, J. D. (2002) 'Evidence for cortical encoding specificity in episodic memory:
Memory-induced re-activation of picture processing areas', Neuropsychologia, Vol. 40, No. 12, pp. 2136-2143.

(74) Ebbinghaus, H. (1885) 'Memory: A Contribution to Experimental Psychology', Chapter 9, Section 37, Teachers College, Columbia University.

(75) Magee, J. C. (2000) 'Dendritic integration of excitatory synaptic input', Nature Reviews. Neuroscience, Vol. 1, No. 3, pp. 181-190.

(76) Dehaene, S., Changeux, J. -P., Naccach, L., Sackur, J. and Sergent, C. (2006) 'Conscious, preconscious, and subliminal processing: A testable taxonomy', Trends in Cognitive Sciences, Vol. 10, No. 5, pp. 204-211.

(77) Van Dellen, A., Blakemore, C., Deacon, R., York, D. and Hannan, A. J. (2000) 'Delaying the onset of Huntington's in Mice', Nature,Vol. 404, No. 6779, pp. 721-722.

(78) Rampon, C., Tang, Y. -P., Goodhouse, J., Shimizu, E., Kyin, M. and Tsien, J. Z. (2000) 'Enrichment induces structural changes and recovery from nonspatial memory deficits in CA1 NMDAR1-knockout mice', Nature Neuroscience, Vol. 3, No. 3, pp. 238-244.

(79) Optale, G., Capodieci, S., Pinelli, P., Zara, D., Gamberini, L. and Riva, G. (2001) 'Musicenhanced immersive virtual reality in the rehabilitation of memoryrelated cognitive processes and functional abilities: A case report', Teleoperators \& Virtual Environments, Vol. 10, No. 4, pp. $450-462$.

(80) Narasimhan, K. (2006) 'More neurons may not make you smarter', Nature Neuroscience, Vol. 9, No. 6, p. 722.

(81) Van Praag, H., Kempermann, G. and Gage, F. H. (1999) 'Running increases cell proliferation and neurogenesis in the adult mouse dentate gyrus', Nature Neuroscience, Vol. 2, No. 3, pp. 266-270.

(82) Spedding, M., Jay, T., Costa e Silva, J. and Perret, L. (2005) 'A pathophysiological paradigm for the therapy of psychiatric disease', Nature Reviews. Drug Discovery, Vol. 4, No. 6, pp. 467-476.

(83) Eichenbaum, H. and Harris, K. (2000) 'Toying with memory in the Hippocampus', Nature Neuroscience, Vol. 3, No. 3, pp. 205-206.

(84) Fischer, A., Sananbenesi, F., Wang, X., Dobbin, M. and Tsai, L. -H. (2007) 'Recovery of learning and memory is associated with chromatin remodelling', Nature, Vol. 447, No. 7141, pp. 178-183.

(85) In the conscious evaluation phase (eg for highinvolvement brands), richness could give rise to a phenomenon that Anderson ${ }^{86}$ and others have observed in certain very active searches of conscious memory and that he has called the 'fan effect'. The fan effect says that the more 
elements a memory contains, the less accessible it becomes. Anderson ${ }^{87}$ also notes, however, that such very active searches are uncommon in daily life and that repeated activation (by Law \# 2) of such memories can neutralise it or even create a negative fan effect.

(86) Anderson, J. R. (1974) 'Retrieval of propositional information from long-term memory', Cognitive Psychology, Vol. 5, No. 4, pp. 451-474.

(87) Anderson, J. R. (1983) 'Retrieval of information from long-term memory', Science, New Series, Vol. 220, No. 4592, pp. 25-30.

(88) Festinger, L. (1957) 'A Theory of Cognitive Dissonance', Stanford University Press, Stanford, CA.

(89) Gromark, J., Astvik, T. B. and Melin, F. (2005) 'Brand Orientation Index', Label AG, Götenborg.

(90) Wagner, A. D., Maril, A., Bjork, R. A. and Schacter, D. L. (2001) 'Prefrontal contributions to executive control: fMRI evidence for functional distinctions within lateral prefrontal cortex', Neuroimage, Vol. 14, pp. 1337-1347, quoted in: Sakai, K., Rowe, J. B. and Passingham, R. E. (2002) 'Active maintenance in prefrontal area 46 creates distractor-resistant memory', Nature Neuroscience, Vol. 5, No. 5, pp. 479-484.

(91) Craik, F. I. M. and Tulving, E. (1975) 'Depth of processing and the retention of words in episodic memory', Journal of Experimental Psychology (General), Vol. 104, No. 3, pp. 268-294.
(92) Court, D. C., Leiter, M. G. and Loch, M. A. (1999) 'Brand leverage', The McKinsey Quarterly, Vol. 36, No. 2, pp. 101-110.

(93) Van der Vorst, R. R. R. (2004) 'Branding: A systems theoretic perspectiveDoctoral Thesis, Radboud University Nijmegen, The Netherlands.

(94) Van der Vorst, R. R. (2004) 'Uniciteit: Anders Zijn Zonder Iets Anders Te Worden', Holland Management Review, Vol. 21, No. 96, pp. 6981.

(95) Loken, B. and Roedder John, D. (1993) 'Diluting brand beliefs: When do brand extensions have a negative impact', Journal of Marketing, Vol. 57, No. 3, pp. 71-84.

(96) Evans, P. and Wurster, T. S. (2000) 'Blown to Bits: How the New Economics of Information Transforms Strategy', Harvard Business School Press, Cambridge.

(97) Lodish, L. M. and Mela, C. F. (2007) 'If brands are built over years, why are they managed over quarters', Harvard Business Review, Vol. 85, No. 7-8, pp. 104-112.

(98) Walvis, T. H. (1995) 'De Prestatie Paradox: Creatieve Spanning en Systematisch Bovengemiddelde Bedrijfsprestaties', unpublished thesis (with a summary in English), Erasmus University Rotterdam.

(99) Collins, J. C. and Porras, J. I. (1994) 'Build to Last: Successful Habits of Visionary Companies', Harper Collins, New York.

(100) Henderson, T. A. and Mihas, E. A. (2000) 'Building retail brands', The McKinsey Quarterly, Vol. 37, No. 3, pp. 110-117. 